\title{
Induction of implantation in the rat by iproniazid*
}

\author{
A. K. Pal and Anita Pakrashi \\ Reproductive Biology Research Section, Indian Institute of Experimental Medicine, \\ 4 Raja S.C. Mullick Road, Calcutta-700032, India
}

\begin{abstract}
Summary. Rats were bilaterally ovariectomized on Day 3 post coitum and treated daily with progesterone. Iproniazid, an inhibitor of monoamine oxidase, on Day 8 induced implantation in all rats. Indomethacin treatment prevented this effect.
\end{abstract}

\section{Introduction}

The involvement of prostaglandins (PGs) in decidual cell development (Castracane, Saksena \& Shaikh, 1974) and implantation (Lau, Saksena \& Chang, 1973; Castracane et al., 1974; Kennedy, 1977) in laboratory animals has been clearly shown. Iproniazid, a potent monoamine oxidase inhibitor recommended as having therapeutic value in mental depression (Koelle, 1970), has an abortifacient action which is mediated through an increased endogenous production of PGs (Chatterjee, Biswas \& Pal, 1974). We therefore studied the ability of iproniazid to induce implantation in rats, and also whether indomethacin, a potent inhibitor of PG biosynthesis and release (Vane, 1971; Ferreira, Moncada \& Vane, 1971; Rankin, Ledford, Jonsson \& Baggett, 1979), can reverse the implantation-inducing effect of iproniazid.

\section{Materials and Methods}

Animals. Inbred albino rats weighing $150-170 \mathrm{~g}$ were used. They were kept in light controlled conditions of $14 \mathrm{~h} \mathrm{light} / 24 \mathrm{~h}$. Pro-oestrous females were caged with males of proven fertility and mating was confirmed by finding spermatozoa in the vaginal smear (Day 1 of pregnancy). Bilateral ovariectomy was performed on Day 3 under light ether anaesthesia. Care was taken to avoid damage to the oviduct. All the rats were killed on Day 12 and the number of implantation sites was recorded.

Drugs and treatments. Iproniazid phosphate, donated by the F. Hoffman La Roche \& Co. Ltd, Basle, Switzerland, was dissolved in distilled water and administered subcutaneously (s.c.) as a single injection $(0.2 \mathrm{ml})$ at a dose of $150 \mathrm{mg} / \mathrm{kg}$ body weight on Day 8. Progesterone (Proluton Dep: Schering, India) was diluted in olive oil and injected s.c. at a dose of $5 \mathrm{mg} / \mathrm{rat} / \mathrm{day}$ from Day 3 to Day 11 p.c. Indomethacin (I.D.P.L., India) was dissolved in olive oil and administered s.c. at $2.5 \mathrm{mg} / \mathrm{kg}(0.2 \mathrm{ml})$ on Days 7,8 and 9 .

\section{Results}

As shown in Table 1 daily injections of progesterone were not able to induce implantation, but a single injection of iproniazid to the progesterone-treated animals was successful. Concomitant administration of indomethacin inhibited the iproniazid-induced implantation.

* Reprint requests to Dr A. Pakrashi. 
Table 1. Effect at Day 12 of iproniazid on implantation in rats bilaterally ovariectomized on Day 3 of pregnancy

\begin{tabular}{lccc}
\hline \multicolumn{1}{c}{$\begin{array}{c}\text { Treatment } \\
\text { (day of pregnancy) }\end{array}$} & $\begin{array}{c}\text { No. of } \\
\text { rats }\end{array}$ & $\begin{array}{c}\text { No. with } \\
\text { implantation sites }\end{array}$ & $\begin{array}{c}\text { Mean } \pm \text { s.e.m. no. of } \\
\text { implantation sites }\end{array}$ \\
\hline $\begin{array}{l}\text { Progesterone (Days 3-11) } \\
\begin{array}{c}\text { Proniazid (Day 8) + } \\
\text { progesterone (Days 3-11) }\end{array}\end{array}$ & 6 & 0 & - \\
$\begin{array}{c}\text { Iproniazid (Day 8) + } \\
\text { progesterone (Days 3-11)+ } \\
\text { indomethacin (Days 7-9) }\end{array}$ & 6 & 7 & $6.66 \pm 0.55$ \\
\hline
\end{tabular}

\section{Discussion}

PGF- $2 \alpha$ treatment in the mouse prevents the inhibitory effect of indomethacin on implantation (Lau et al., 1973). Iproniazid acts by interfering with the metabolism of catecholamines (Koelle, 1970) which can stimulate the release of prostaglandins in the spleen (Ferreira et al., 1971). Moreover, indomethacin blocks the conversion of arachidonic acid to endoperoxides (Flower \& Vane, 1974).

Cyclic AMP is also able to induce implantation (Webb, 1975) and $\beta$-adrenergic catecholamine can stimulate adenylate cyclase in pigeon erythrocytes (Davoren \& Sutherland, 1963). Endometrial adenylate cyclase is also known to be stimulated by PGE-1 and PGE-2 (Bhalla, Sanborn \& Korenman, 1972). The formation of cAMP by cyclo-oxygenase in uterine decidual tissue is inhibited by indomethacin (Rankin et al., 1979).

\section{References}

Bhalla, R.C., Sanborn, B.M. \& Korenman, S.G. (1972) Hormonal interactions in the uterus: Inhibition of isoproterenol-induced accumulation of adenosine $3^{\prime} 5^{\prime}$ cyclic monophosphate by oxytocin and prostaglandins. Proc. natn. Acad. Sci. U.S.A. 69, 3761-3764.

Castracane, V.D., Saksena, S.K. \& Shaikh, A.A. (1974) Effect of intrauterine devices, prostaglandin and indomethacin on decidual cell reaction in rat. Prostaglandins. 6, 397-404.

Chatterjee, A., Biswas, L. \& Pal, A.K. (1974) Aspirin and the reversal of antifertility effect of iproniazid in rats. Prostaglandins. 7, 285-291.

Davoren, P.R. \& Sutherland, E.W. (1963) The effect of L-Epinephrine and other agents on the synthesis and release of adenonine $3^{\prime} 5^{\prime}$ phosphate by whole pigeon erythrocytes. J. biol. Chem. 238, 3009-3015.

Ferreira, S.H., Moncada, S. \& Vane, J.R. (1971) Indomethacin and aspirin abolish prostaglandin release from spleen. Nature, New Biol. 321, 237-239.

Flower, R.J. \& Vane, J.R. (1974) Some pharmacological and biochemical aspects of prostaglandin biosynthesis and its inhibition. In Prostaglandin Synthetase Inhibitors, pp. 9-18. Eds H. J. Robinson \& J. R. Vane. Raven Press, New York.
Kennedy, T.G. (1977) Evidence for a role of prostaglandins in the initiation of blastocyst implantation in the rat. Biol. Reprod. 16, 286-291.

Koelle, G.B. (1970) Drug acting at synaptic and neuroeffector junctional sites. In The Pharmacological Basis of Therapeutics, pp. 402-441. Eds L. S. Goodman \& A. Gillman. Macmillan, New York.

Lau, I.F., Saksena, S.K. \& Chang, M.C. (1973) Pregnancy blocked by indomethacin an inhibitor of prostaglandin synthesis. Reversal by prostaglandins and progesterone in mice. Prostaglandins 4, 795805.

Rankin, J.C., Ledford, B.E., Jonsson, H.T., Jr \& Baggett, B. (1979) Prostaglandins, indomethacin and decidual cell reaction in the mouse uterus. Biol. Reprod. 20, $399-404$.

Vane, J.R. (1971) Inhibition of prostaglandin synthesis as a mechanism of action for aspirin-like drugs. Nature, New Biol. 321, 232-235.

Webb, F.T.G. (1975) Implantation in ovariectomized mice treated with dibutyryl adenosine $3^{\prime} 5^{\prime}$ monophosphate (dibutyryl cyclic AMP). J. Reprod. Fert. 42, 511-517. 